\title{
ASSESSMENT OF TRACE METALS USING CHEMOMETRIC ANALYSIS IN KUANTAN RIVER, EAST COAST MALAYSIA
}

\author{
Fikriah Faudzi ${ }^{*}$, Kamaruzzaman Yunus ${ }^{1}$, Mohd Fuad Miskon², Azman Azid ${ }^{3}$ \\ ${ }^{1}$ Kulliyyah of Science, International Islamic University Malaysia, Jalan Sultan Ahmad Shah, Bandar Indera Mahkota, 25200 Kuantan, Pahang, \\ Malaysia, \\ ${ }^{2}$ Institue of Oceanography and Maritime Studies, International Islamic University Malaysia, Jalan Sultan Ahmad Shah, Bandar Indera Mahkota, \\ 25200 Kuantan, Pahang, \\ ${ }^{3}$ Faculty of Bioresources and Food Industry, Universiti Sultan Zainal Abidin, Besut Campus, 22200 Besut, Terengganu, Malaysia. \\ *Corresponding author's e-mail: fikriahf@iium.edu.my
}

This is an open access article distributed under the Creative Commons Attribution License, which permits unrestricted use, distribution, and reproduction in any medium, provided the original work is properly cited.

\section{ARTICLE DETAILS}

\section{Article History:}

Received 01 February 2019 Accepted 14 March 2019 Available online 6 May 2019

\section{ABSTRACT}

Chemometric techniques were applied to identify and assess the trace metals of Kuantan River water. Water samples from nine sampling stations were taken from downstream of the estuary towards the upstream of Kuantan River. The following trace metals were selected for analysis i.e. $\mathrm{Hg}, \mathrm{Cd}, \mathrm{Pb}, \mathrm{As}$, $\mathrm{Co}$ and $\mathrm{Cr}$. To evaluate chemical variation on the variables, multivariate statistical methods like principal components analysis (PCA), cluster analysis (CA) and discriminant analysis (DA) were performed. The homogeneity characteristics between the stations were integrated by cluster analysis, which were represented by dendrograms and were classified according to their surrounded activities. PCA was identified four factors namely $\mathrm{Cr}, \mathrm{Hg}, \mathrm{Pb}$ and Co explaining $77.8 \%$ of the total variance. PCA revealed that Kuantan River is strongly affected by point sources such as commercial wastewater, industries and non-point sources especially from agriculture activities. The CA classified three clusters as commercial centre (CC), residential areas (RA) and agricultural areas (AA). AA located in the upstream is less polluted than RA, while CC located in the downstream is more polluted than RA. These statistical approaches and results yielded useful information including identification of pollution sources/factors and understanding temporal variations in river water for effective river water quality management.

KEYWORDS

Trace Metals, River water, Chemometrics, Multivariate Statistical Analysis.

\section{INTRODUCTION}

River basin has been a major source of water supply for many purposes and provides fertile lands, which support the development of highly populated residential areas due to its favorable conditions [1]. Human settlements and industries have long been concentrated along rivers, estuaries, and coastal zones owing to the predominance of water-borne trade. Rivers constitute the main inland water body for domestic, industrial, and agricultural activities and often carry large municipal sewage, industrial wastewater discharges, and seasonal runoff from an agricultural field. The river waters have been contaminated as a result of the discharges of wastewater containing degradable organics, nutrients, domestic effluent and agricultural waste [2].

The decline in the quality and quantity of surface water resources can be attributed to water pollution and the improper management of the resource [3]. From the environmental, economic, and/or social point of view, it is important to identify these sources and their contribution to the total contamination of an area [4]. The combined use of chemometric tools such as multivariate statistical techniques enables the classification of water samples into distinct groups, source apportionments, relationship and differences in the parameters used based on hydrochemical characteristics [5]. The aim of this study was to apply the chemometric methods on trace metals data set of Kuantan River in order to identify sources of pollution and explicit latent factors responsible for spatial variations.

\section{MATERIALS AND METHODS}

\subsection{Study Sites}

Kuantan River Basin is located adjacent to the Tanjung Lumpur mangrove in Kuantan district, Pahang and flowing out to the South China Sea. Map of the sampling stations in Kuantan River basin are shown in Figure 1.

\subsection{Sampling and Analytical Methods}

All glassware and plastic wares were immersed in $10 \%$ nitric acid $\left(\mathrm{HNO}_{3}\right)$, rinsed and dried before use. Nylon membrane filters paper $(47 \mathrm{~mm}$ diameter, Whatmann) with pore size of $0.45 \mu \mathrm{m}$ were immersed in $10 \%$ $\mathrm{HNO}_{3}$, washed, dried in class 100 laminar flow hood and filters were weighed [6]. Surface and bottom water samples were collected from May 2012 till October 2012 from 9 stations using Van-Dorn Water Sampler. Hydrological general physicochemical parameters such as temperature, salinity, $\mathrm{pH}$ and dissolved oxygen (DO) were measured in-situ using YSI Hydrolab multisensory probe. Water samples were kept in ice during the transportation to the laboratory. Water samples were filtered through a low-pressure vacuum pump within 24 hours. The membrane filter was dried, weight and re-weighed until constant weight obtained and labeled as the particulate sample. 


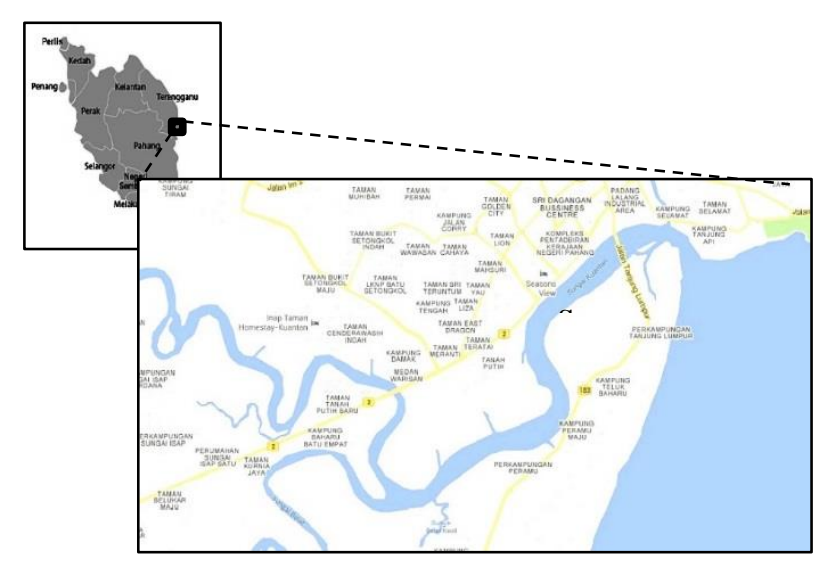

Figure 1: Map of the sampling stations in Kuantan River

Water samples that passed through the membranes were considered as dissolved phase were extracted with Chelex-100 pre-concentration method [6]. Chelex-100 was weighed to $2.0 \mathrm{~g}$ was soaked in $2.5 \mathrm{M}$ HNO3 for 72 hours. Then, Chelex-100 was loaded cautiously into the column in which the ends of the column were blocked with a small amount of glass wool. Solvents, deionized water, buffer, eluent and samples were passed through the column using peristaltic pump at the optimum flow rate of 2 $\mathrm{ml} \mathrm{min}^{-1}$. Then, water samples were eluted with $2 \mathrm{M} \mathrm{HNO}_{3}$. Samples were diluted with Milli-Q water (18.2 M $\Omega$ ) before detected by ICP-MS. Samples were carried out in triplicate to obtain accuracy.

Particulate samples were added together with $1.5 \mathrm{~mL}$ of mixed acid with the ratio of $3.5 \mathrm{HNO}_{3}: 3.5$ Hydrochloric acid $(\mathrm{HCl}): 3$ Hydrofluoric acid (HF) in a Teflon vessel and heated for 5 hours at $150{ }^{\circ} \mathrm{C}$ [7]. After cooling session, sample were added with $3 \mathrm{~mL}$ of mixed of boric acid $\left(\mathrm{H}_{3} \mathrm{BO}_{3}\right)$ and EDTA. Then, sample were heated again for 5 hours at $150{ }^{\circ} \mathrm{C}$ in the microwave oven. Samples digestion was carried out in triplicat to ensure the reproducibility of the method. Procedural blanks and quality control samples were analyzed for every ten samples in order to check for sample accuracy. Recovery test for particulate metals was conducted using SRM 1646a Estuarine Sediment ranged from $98 \%$ to $105 \%$. Concentration of particulate metal concentration was calculated using the Eq. 1:

$$
m=\frac{v \times w \times d}{x}
$$

Where $m$ is the particulate metal concentration $\left(\mu \mathrm{g} \mathrm{g}^{-1}\right), v$ is the ICP-MS value, $w$ is the sample weight, $d$ is the dilution factor and $x$ is the sample dry weight $(\mathrm{g})$.

\subsection{Cluster Analysis (CA)}

The data set was subjected to CA to identify clusters of the sampling sites indicating their similarity based on the variables [8]. Six heavy metals and and five physicochemical parameters measured from nine sites were subjected to CA analysis. CA was performed on the mean values of the variables.

\subsection{Discriminant Analysis (DA)}

DA was used to determine the variables that best discriminate between groups that was identified by CA. The basic idea underlying DA is to determine whether groups differ with regard to mean of a variable, and then to use that variable to predict group membership.

The DA technique was operated on the raw data and a discriminant function was constructed for each group, as in the Eq. 2 [9]:

$f\left(G_{i}\right)=k_{i}+\sum_{j=1}^{n} W_{i j} P_{i j}$

Where $i$ is the number of groups (G), $k_{i}$ is the constant inherent to each group, $n$ is the number of parameters used to classify a set of data into a given group, $W_{i j}$ is the weight coefficient, assigned by DA to a given selected parameters $\left(P_{i j}\right)$. The weight coefficient maximizes the distance between the means of the criterion (dependent) variable.

\subsection{Principal Component Analysis (PCA)}

PCA are statistical approaches to analyze interrelationships among a large number of variables and to explain these variables in terms of their common underlying dimension by providing empirical estimates of the structure of the variables [10]. PCA is about extracting a set of independent linear combination of the parameters and transforming into a smaller set of independent variables (principal components) with minimum loss of original information $[11,12]$. PCA can be calculated using Eq. 3:

$f i j+f j 1 z i 1+f j 2 z i 2+\ldots \ldots f j m z m+e i j$

where $j$ is the measured variable, $f$ is the factor loading, $z$ is the factor score, $e$ is the residual term accounting for errors, $i$ is the sample number, and $m$ is the total number of factors.

This study applies varimax rotation in which the value of PCA can be cleared up by means of a rotation procedure of the eigenvalue [13]. The main purpose of using rotational methods is to achieve a simpler and more eloquent representation of the underlying factors, producing a new group of variables known as varimax factors (VFs) [14]. Varimax factor (VF) coefficient with a correlation of $>0.75$ are explained as strong significant factor loading [15]. While correlation ranges from $0.75-0.50$ and $0.50-0.30$ are considered as moderate and weak factor loading, respectively.

\section{RESULTS AND DISCUSSION}

Descriptive statistics of elements content in water samples collected from Kuantan river indicated in Table 1. The average levels of As, $\mathrm{Hg}, \mathrm{Cd}$, Cr, Co and $\mathrm{Pb}$ was $26.12 \pm 15.37 \mu \mathrm{g} \mathrm{L}{ }^{-1}, 0.25 \pm 0.24 \mu \mathrm{g} \mathrm{L}^{-1}, 2.60 \pm 2.76 \mu \mathrm{g} \mathrm{L}^{-1}, 0.59$ $\pm 0.49 \mu \mathrm{g} \mathrm{L}^{-1}, 0.67 \pm 0.53 \mu \mathrm{g} \mathrm{L}^{-1}$ and $10.07 \pm 9.92 \mu \mathrm{g} \mathrm{L}^{-1}$, respectively. The results of statistical analysis showed that the mean concentrations of As, $\mathrm{Hg}, \mathrm{Cd}, \mathrm{Cr}$ and $\mathrm{Pb}$ were lower than the permissible limit of based on National Water Quality Standard (NWQS) that is, $50 \mu \mathrm{g} \mathrm{L}^{-1}, 1 \mu \mathrm{g} \mathrm{L} \mathrm{L}^{-1}, 10 \mu \mathrm{g}$ $\mathrm{L}^{-1}, 50 \mu \mathrm{g} \mathrm{L}-1$ and $50 \mu \mathrm{g} \mathrm{L}^{-1}$, respectively [16].

Table 1: Descriptive statistic of heavy metals in Kuantan River ( $\mu \mathrm{g} \mathrm{L}^{-1}$ )

\begin{tabular}{|l|c|c|c|c|}
\hline Variable & Minimum & Maximum & Mean & Std. deviation \\
\hline $\mathrm{As}$ & 0.00 & 69.40 & 26.12 & 15.37 \\
\hline $\mathrm{Cd}$ & 0.00 & 13.00 & 2.60 & 2.76 \\
\hline $\mathrm{Cr}$ & 0.00 & 2.08 & 0.59 & 0.49 \\
\hline $\mathrm{Hg}$ & 0.00 & 0.94 & 0.25 & 0.24 \\
\hline $\mathrm{Pb}$ & 0.00 & 42.70 & 10.07 & 9.92 \\
\hline $\mathrm{Co}$ & 0.00 & 2.51 & 0.67 & 0.53 \\
\hline Temperature & 27.24 & 30.40 & 29.30 & 0.89 \\
\hline Salinity & 0.09 & 34.41 & 18.72 & 10.56 \\
\hline $\mathrm{pH}$ & 6.02 & 8.01 & 6.86 & 0.44 \\
\hline DO & 4.02 & 7.83 & 5.68 & 0.87 \\
\hline Rainfall & 181.60 & 288.60 & 229.46 & 44.61 \\
\hline
\end{tabular}

In this study, four varifactors (VFs) with eigenvalues $>1$ that explained about $77.8 \%$ of the total variance in the data set. The corresponding VFs, variable loadings and the explained variance are presented in Table 2. Varifactor 1 (VF1), which explained $34.4 \%$ of the total variance, had strong positive loadings on $\mathrm{Cr}$ and negative strong loadings on DO. Cr could have been due to the emanation of combustion of fossil fuels, commercial wastes and sewage sludge. These reactions increase the utilization of $\mathrm{O}_{2}$, which results to the low DO $[17,18]$. VF2, which accounted for $19.1 \%$ of the total variance, had strong positive loadings on As, salinity and $\mathrm{pH}$ $[19,20]$. This factor may attribute to the machinery factories and warehouses, diverse constructions especially located in the downstream of the river, where high salinity and $\mathrm{pH}$ presence.

The third group, VF3 (14.6\% of total variance) had strong positive loadings on $\mathrm{Hg}$. $\mathrm{Hg}$ effluents may originate from dental practices, thermometer, and clinical discharges from a nearby hospital as well as domestic discharges from the household products such as disinfectant products (bleach) [21]. Lastly, VF4 accounted for $9.7 \%$ of the total variance 
had strong positive loadings on Cd (Table 2). Cd could be generated from weathering and erosion of soils due to the dispersive use of fertilizers from agricultures areas $[19,22]$.

Kuantan River and the adjoining areas have many small and mid-scale industrial units that use these significant elements for various value-added products and discharge their untreated wastes into the river. Heavily urbanized city center nearby the Kuantan River also may contributed to the significant amounts of metals into the waters through their activities such as agricultural, boating and recreational activities, domestic sewages from surface run-off as well as drains discharged into the river water.

Table 2: Eigenvalues from principal component analysis shows variability, cumulative and factor loadings.

\begin{tabular}{|l|c|c|c|c|}
\hline & F1 & F2 & F3 & F4 \\
\hline Eigenvalue & 3.780 & 2.105 & 1.610 & 1.066 \\
\hline Variability (\%) & 34.364 & 19.137 & 14.633 & 9.687 \\
\hline Cumulative (\%) & 34.364 & 53.501 & 68.134 & 77.821 \\
\hline $\mathrm{As}$ & -0.167 & 0.865 & 0.068 & 0.221 \\
\hline $\mathrm{Hg}$ & 0.216 & -0.042 & 0.900 & -0.009 \\
\hline $\mathrm{Cd}$ & -0.083 & 0.145 & -0.017 & 0.901 \\
\hline $\mathrm{Cr}$ & 0.803 & -0.056 & 0.202 & 0.225 \\
\hline $\mathrm{Pb}$ & -0.211 & 0.534 & 0.533 & 0.000 \\
\hline $\mathrm{Co}$ & 0.616 & 0.211 & 0.236 & 0.454 \\
\hline Temperature & 0.636 & 0.628 & 0.018 & -0.074 \\
\hline Salinity & 0.240 & 0.831 & 0.107 & 0.077 \\
\hline $\mathrm{pH}$ & 0.366 & 0.784 & -0.384 & 0.015 \\
\hline Dissolved Oxygen & -0.845 & -0.146 & -0.056 & 0.306 \\
\hline Rainfall & -0.651 & -0.121 & 0.468 & 0.191 \\
\hline
\end{tabular}

Results from CA indicate that the sampling sites have similar heavy metal contribution and are clustered together. The output demonstrates that the sampling sites of heavy metals are grouped into three distinctive clusters in the hierarchical dendrogram (Figure 2). Station 1 and 2 were successfully integrated into cluster 1 . Station 3, 4, 5 and 6 were integrated into cluster 2, station 7, 8 and 9 were integrated into cluster 3. Based on the cluster obtained from CA, stations in those clusters are employing the similar characteristic of their land use activities, characterized by the similar source of contamination and level of pollutants with regards to sampling location. Cluster 1 is categorized as commercial centre (CC) has moderate pollution, while cluster 2 is categorized as residential areas (RA) was less polluted than cluster 1 but more polluted than cluster 3 , which categorized as agricultural areas (AA).

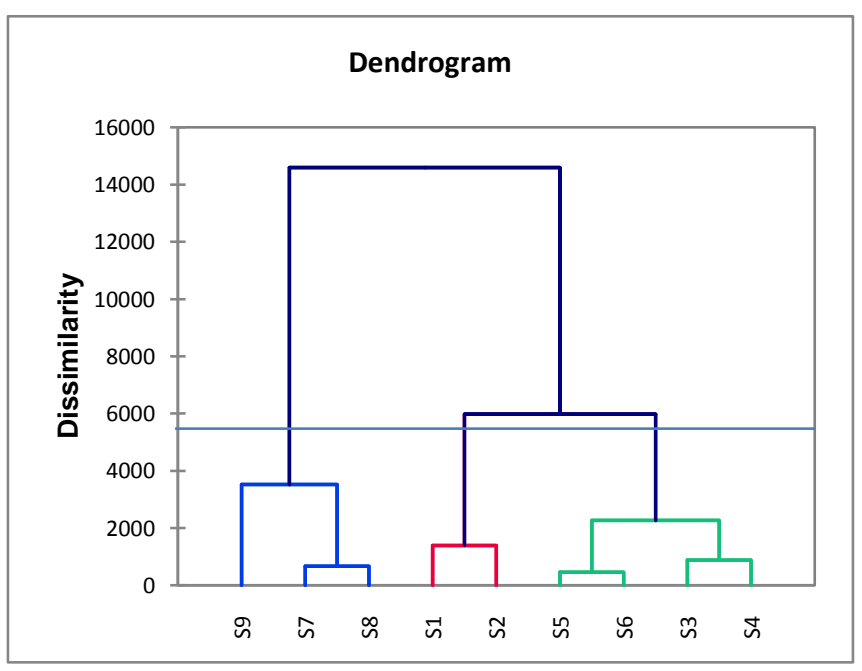

Figure 2: Cluster Analysis of Kuantan River

After clustering the sampling sites into three group, DA was performed on the dataset to explore the similar classification matrixes of trace metal pollution in Kuantan River. DA was also performed on the original data set to test the significance of the cluster analysis and to establish the significance of the parameters of the clusters. The clusters (CC, RA and AA) were treated as dependent variables and the heavy metals and physicochemical parameters as independent variables.
With the standard mode DA, the sampling sites were discriminated to 85.19\% classification matrix accuracy, performed by discriminant function (DF's) with nine discriminant variables. Standard mode DA reveals that all variables except $C d$ and rainfall are the significant variables with value of $\mathrm{p}<0.05$. On the other hand, forward stepwise mode was discriminated to $82.41 \%$ and backward stepwise mode has the accuracy of $86.11 \%$, with five and four discriminant variables, respectively. The four most significant variables that are determined via the forward stepwise DA constitute the most optimum number of heavy metals required for further consideration in future spatial monitoring of contaminants along the Kuantan River. Output from DA clearly shows that this technique is a useful tool to identify the discriminating variables in the spatial variance of the heavy metals.

\section{CONCLUSION}

This study has shown that based on the data collected on heavy metals along the Kuantan River. PCA reveals that there are four factors found for $77.82 \%$ of the total heavy metal variation. Further analyses by CA reveal three cluster knowns as commercial areas, residential areas and agricultural areas, which then confirm by DA. These heavy metal pollutants can be attributed to various anthropogenic activities related to the urban development and industries. From the application of various chemometric tools, monitoring of heavy metals can be optimized, and concurrently it can save time and reduce the cost of monitoring. Consequently, a timesaving, cost effective regime of heavy metal monitoring based on the finding of this study should be designed by the relevant authorities to ensure continuous observation of these pollutants.

\section{ACKNOWLEDGEMENT}

Millions of thanks to staff of Kulliyyah of Science, International Islamic University Malaysia for their kind assistance. This research was funded by the Research Initiative Grant Scheme (RIGS) ID 16-321-0485 of International Islamic University Malaysia (IIUM).

\section{REFERENCES}

[1] Mouri, G., Takizawa, S., Oki, T. 2011. Spatial and temporal variation in nutrient parameters in stream water in a rural-urban catchment, Shikoku, Japan: effects of land cover and human impact. J Environ Manage, 92 (7),1837-1848.

[2] Dimitrovska, O., Markoski, B., Toshevska, B.A., Milevski, I., Gorin, S. 2012. Surface water pollution of major rivers in the Republic of Macedonia. Procedia Environmental Sciences, 14, 32-40. doi: 10.1016/j.proenv.2012.03.004

[3] Mustapha, A., Nabegu, A.B. 2011. Surface water pollution source identification using principal component analysis and factor analysis in Getsi River, Kano, Nigeria. Austr J Basic Appl Sci, 5, 1507-1512.

[4] Tobiszewski, M., Tsakovski, S., Simeonov, V., Namiesnik, J. 2010. Surface water quality assessment by the use of combination of multivariate statistical classification and expert information. Chemosphere, 80 (7), 740-746.

[5] Shrestha, S., Kazama, F., Nakamura, T. 2008. Use of principal component analysis, factor analysis and discriminant analysis to evaluate spatial and temporal variations in water quality of the Mekong River. J Hydroinform, 10 (1), 43-56.

[6] APHA, American Public Health Agency. 2017. Standard methods for the examination of water and wastewater (10 ${ }^{\text {th }}$ Ed.). Washington, District of Columbia. doi: 10.2105/ SMWW.2882.039.

[7] Kamaruzzaman, B.Y., Zahir, M.Z., Akbar John, B., Siti Waznah, S., Jalal, K.C.A., Shahbudin, S., Al-Barwani, S.M., Goddard, J.S. 2010. Determination of Some Heavy Metal Concentrations in Razor Clam from Tg. Lumpur Coastal Waters, Pahang, Malaysia. Pakistan Journal of Biological Sciences, 13 (24), 1208-1213.

[8] Wan Mohd Khalik, W.M.A., Abdullah, M.P., Al-Qaim, F.F. 2015. Chemometric Application on Surface River Water Quality: A Case Study of Linggi River, Malaysia. Iranica. Journal of Energy and Environment, 6 (1), 26- 34. 
[9] Azid, A., Juahir, H., Toriman, M.E., Endut, A., Kamarudin, M.K.A., Rahman, M.N.A., Hasnam, C.N.C., Saudi, A.S.M., Yunus, K. 2015. Source Apportionment of Air Pollution: A Case Study In Malaysia. Jurnal Teknologi, 72, 83-88. doi: 10.11113/jt.v72.2934.

[10] Low, K.H., Koki, I.B., Juahir, H., Azid, A., Behkami, S., Ikram, R., Mohammed, H.A., Zain, S.M. 2016. Evaluation of water quality variation in lakes, rivers, and ex-mining ponds in Malaysia. Desalination and Water Treatment, 57 (58), 28215-28239.

[11] Khalit, S.I., Samsudin, M.S., Azid, A., Yunus, K., Zaudi, M.A., Sharifuddin, S.S., Husin, T.M. 2017. A preliminary study of marine water quality status using principal component analysis at three selected mangrove estuaries in East Coast Peninsular Malaysia. Malaysian Journal of Fundamental and Applied Sciences, 13 (4), 764-768.

[12] Sulaiman, N.H., Khalit, S.I., Sharip, Z., Samsudin, M.S., Azid, A. 2018. Seasonal variations of water quality and heavy metals in two ex-mining lake using chemometric assessment approach. Malaysian Journal of Fundamental and Applied Sciences, 14 (1), 67-72.

[13] Helena, B., Pardo, R., Vega, M., Barrado, E., Fernandez, J., Fernandez, L. 2000. Temporal evolution of groundwater composition in an alluvial aquifer (Pisuerga River, Spain) by principal component analysis. Water Res, 34 (3), 807-816.

[14] Samsudin, M.S., Azid, A., Khalit, S.I., Saudi, A.S.M., Zaudi, M.A. 2017a. River water quality assessment using APCS-MLR and statistical process control in Johor River Basin, Malaysia. International Journal of Advanced and Applied Sciences, 4 (8), 84-97.

[15] Liu, C.W., Lin, K.H., Kuo, Y.M. 2003. Application of factor analysis in the assessment of groundwater area in Taiwan. The Science of the Total Environ, 313, 77-89.
[16] DOE, Department of Environment. 2010. National Water Quality Standard, Official Website of Department of Environmental. http/www.doe.gov.my.

[17] Sekhavatjou, M.S., Rostami, A., Alhasemi, A.S.H. 2010. Assesment of elemental concentrations in the urban air (case study: Tehran City) Environ Monit Assess, 163, 467-476. doi: 10.1007/s10661-0090850-8.

[18] Rathor, G., Chopra, N., Adhikari, T. 2014. Nickel as a Pollutant and its Management. International Research Journal of Environment Sciences, $3(10)$.

[19] WHO, World Health Organization. 2004. Manganese and its compounds: Environmental aspects. Concise international chemical assessment document, CICAD 63. WHO, Geneva. Retrieved from http://www.who.int/ipcs/publications/cicad/cicad63_rev_1.pdf

[20] U.S.EPA, U.S. Environmental Protection Agency. 2013. 5.9 Conductivity. <https://archive. epa.gov/water/archive/web/html/vms59.html> (Retrieved March 16).

[21] Thornton, I., Butler, D., Docx, P., Hession, M., Makropoulos, C., McMullen, M., Nieuwenhuijsen, M., Pitman, A., Rautiu, R., Sawyer, R., Smith, S., White, D. 2001. Pollutants in Urban Waste Water and Sewage Sludge. Final Report to Directorate-General Environment. I C Consultants Ltd London.

[22] Carolin, F.C., Kumar, S.P., Saravanan, A., Janet Joshiba, G., Naushad, M. 2017. Efficient Techniques for the Removal of Toxic Heavy Metals from Aquatic Environment: A Review. Journal of Environmental Chemical Engineering, http://dx.doi.org/10.1016/ j.jece.2017.05.029. 